\title{
PENGARUH DEFOLIASI DAN LAMA PENYIMPANAN ENTRES TERHADAP KEBERHASILAN SAMBUNG PUCUK BIBIT KAKAO (Theobroma cacao L.)
}

\author{
Syukri $^{1}$, Boy Riza Juanda ${ }^{1}$, Supriyadi ${ }^{2}$ \\ ${ }^{1}$ Dosen rogram Studi Agroteknologi, Fakultas Pertanian Universitas Samudra \\ ${ }^{2}$ Alumni Program Studi Agroteknologi, Fakultas Pertanian Universitas Samudra \\ e-mail: Syukri@unsam.ac.id
}

\begin{abstract}
ABSTRAK
Penelitian bertujuan untuk mengetahui pengaruh defoliasi entres dan lama penyimpanan entres terhadap keberhasilan sambung pucuk bibit kakao (Theobroma cacao. L)". Penelitian ini telah dilaksanakan di dua lokasi, defoliasi dan penyimpanan entres dilakukan di Desa Balee Panah Kecamatan Juli Kabupaten Bireun dan penyambungan di Desa Paya Bujuk Seuleumak Kota Langsa, waktu penelitian bulan September sampai dengan November 2018. Penelitian ini menggunakan Rancangan Acak Kelompok (RAK) pola faktorial, yang terdiri dari dua faktor yaitu: Faktor lama defoliasi entres (D) dan faktor lama penyimpanan entres dilakukan setelah defoliasi $(\mathrm{P})$ masing-masing terdiri atas 4 taraf. Hasil penelitian menunjukkan bahwa perlakuan defoliasi berpengaruh sangat nyata terhadap persentase bibit jadi, waktu muncul mata tunas, panjang tunas dan jumlah daun. Hasil pengamatan terbaik diperoleh pada perlakuan $\mathrm{D}_{2}$ (defoliasi entres dilakukan 12 hari sebelum penyambungan). Lama penyimpanan entres berpengaruh sangat nyata terhadap persentase bibit jadi, waktu muncul mata tunas, panjang tunas dan jumlah daun. Hasil pengamatan terbaik diperoleh pada perlakuan $\mathrm{P}_{0}$ (tanpa penyimpanan). Tidak terdapat interaksi antara kedua perlakuan.
\end{abstract}

Kata kunci : Defoliasi, entres, penyimpanan

\begin{abstract}
PENDAHULUAN
Indonesia merupakan negara terbesar ketiga mengisi pasokan kakao dunia yang diperkirakan mencapai $20 \%$ bersama negara Asia lainnya seperti Malaysia, Filipina dan Papua New Guinea (Wahyudi $d k k ., 2009)$. Menurut Data Biro Pusat Statistik (2014) sebagai produsen kakao terbesar ke 3 di dunia nilai ekspor Indonesia akan komoditas kakao selalu meningkat tiap tahunnya. Pada tahun 2013, ekspor kakao Indonesia sebesar 414,1 ton
\end{abstract}

dan pada tahun 2014 menjadi 450,2 ton (meningkat $8,71 \%$ ).

Peningkatan tersebut sebagian besar disebabkan oleh meningkatnya jumlah tanaman produktif sementara laju produktivitas tanaman per hektar per tahun cenderung menurun, akibat pemakaian bahan tanam kakao yang tidak unggul mengakibatkan pencapaian produktivitas dan mutu biji kakao yang rendah. Oleh karena itu, sebaiknya digunakan bahan tanam yang unggul dan bermutu tinggi. 
Untuk meningkatkan kualitas dan pengembangan bibit tanaman kakao, maka perlu dilakukan teknik perbanyakan bibit kakao secara vegetatif. Teknik perbanyakan vegetatif yang selama ini dilakukan oleh petani masih kurang efisien, baik dalam hal waktu maupun teknis pelaksanaannya, sehingga kemampuan penyediaan bibit kakao unggul masih terbatas dan harganya pun relatif tinggi. Salah satu keistimewaan bibit kakao hasil perbanyakan dengan cara vegetatif yaitu tanaman yang dihasilkan mempunyai kualitas yang tinggi yaitu tidak menyimpang dari sifat induknya dan masa panen lebih cepat. Salah satu teknik perbanyakan vegetatif yaitu dengan cara sambung pucuk.

Bibit tanaman hasil dari perbanyakan vegetatif asal sambungan akan menghasilkan pertumbuhan dan produksi yang lebih seragam dibandingkan dengan perbanyakan generatif. Perbanyakan secara sambung pucuk persentase tumbuh lebih tinggi, pekerjaannya lebih sederhana dan pertumbuhannya lebih cepat serta produktifitasnya lebih tinggi jika dibandingkan dengan cara perbanyakan vegetatif lainnya (Lukman 2004).

\section{Untuk meningkatkan}

persentase keberhasilan dalam perbanyakan bibit kakao dengan cara tehnik penyambungan yaitu dengan cara defoliasi pada cabang entres. Defoliasi adalah pemangkasan daun dengan tujuan untuk mengarahkan translokasi fotosintat dan mengatur keseimbangan hormon untuk merangsang pertumbuhan sambungan defoliasi dapat dilakukan dengan merontokan daun yaitu dengan cara menggunting daun kakao pada cabang yang akan dijadikan entres dalam beberapa hari sebelum dilakukan penyambungan.

Menurut Sudarto (2000) defoliasi pada cabang entres dapat mendukung persentase sambung jadi dan mempercepat pertumbuhan tunas pada batang atas. Hal ini disebabkan karena ada kaitannya dengan kandungan asimilat yang terakumulasi pada cabang entres yang didefoliasi. Dimana akumulasi hasil asimilat dapat merangsang pembelahan, pembesaran dan deferensiasi sel yang kemudian mendorong proses pertautan antara batang atas dan batang bawah.

Batang atas yang biasanya disebut entres adalah calon bagian atas atau tajuk tanaman yang di kemudian hari akan menghasilkan buah berkualitas unggul. Kendala yang sering dihadapi dalam perbanyakan sambung pucuk adalah jauhnya jarak antara pohan induk dengan lokasi pembibitan. Entres yang digunakan dalam

sambung pucuk harus dalam keadaan segar, akan tetapi kenyataan di lapangan sering terjadi penundaan penggunaan bahan entres yang sudah diambil. Penelitian bertujuan untuk mengetahui pengaruh defoliasi entres dan lama penyimpanan entres terhadap keberhasilan sambung pucuk bibit kakao (Theobroma cacao. L)".

\section{METODE PENELITIAN}

Penelitian ini telah dilaksanakan di dua lokasi, defoliasi dan penyimpanan entres dilakukan di Desa Balee Panah Kecamatan Juli Kabupaten Bireeun dan penyambungan di Desa Paya Bujuk Seuleumak Kota Langsa, waktu penelitian bulan September sampai dengan November 2018. 
Alat-alat yang digunakan: cangkul, parang, meteran, gembor, hand sprayer, ember, alat tulis menulis, kamera, pisau, gunting okulasi dan jangka sorong.

Bahan-bahan yang digunakan: entres kakao (diperoleh dari kebun petani masyarakat binaan koperasi kakao Bireun), bibit kakao, paranet, kayu, bambu, plastik es lilin, tali rafia, triplek, paku, cat, papan nama, ajir, papan perlakuan dan papan plot.

Penelitian ini menggunakan Rancangan Acak Kelompok (RAK) pola faktorial, yang terdiri dari dua faktor yaitu:

1. Faktor lama defoliasi entres (D) yang terdiri atas 4 taraf yaitu :

$\mathrm{D}_{0}=$ tanpa defoliasi

$\mathrm{D}_{1}=$ defoliasi entres dilakukan 6 hari sebelum penyambungan

$\mathrm{D}_{2}=$ defoliasi entres dilakukan 12 hari sebelum penyambungan

$\mathrm{D}_{3}=$ defoliasi entres dilakukan 18 hari sebelum penyambungan

2. Faktor lama penyimpanan entres dilakukan setelah defoliasi (P) terdiri atas 4 taraf yaitu :

$\mathrm{P}_{0}=$ tanpa penyimpanan

$\mathrm{P}_{1}=3$ hari penyimpanan

$\mathrm{P}_{2}=6$ hari penyimpanan

$\mathrm{P}_{3}=9$ hari penyimpanan

Dengan demikian diperoleh 16 kombinasi perlakuan setiap perlakuan diulangi 2 kali, sehingga terdapat 32 satuan percobaan. Dalam satu plot terdiri dari 4 bibit sambung yang diamati sehingga jumlah tanaman keseluruhan yaitu 128 tanaman.

Model matematika yang digunakan dalam penelitian ini adalah (Hanafiah, 2014):

$$
Y_{i j k}=\mu+\beta_{i}+D_{j}+P_{k}+D P_{(j k)}+\varepsilon_{i j k}
$$

Data yang diperoleh dianalisis dengan menggunakan sidik ragam (annova) pada tingkat signifikan $1 \%$ dan 5\%. Terhadap perlakuan yang berpengaruh nyata dan sangat nyata akan dilanjutkan dengan uji Beda Nyata Terkecil (BNT) taraf 5\%.

\section{Persiapan batang bawah dan batang atas (entres)}

\section{Batang bawah}

Bibit kakao yang digunakan untuk batang bawah berasal dari perbanyakan secara generatif (Biji) yang sudah berumur lebih dari 6 bulan, bibit yang digunakan jenis bibit klon TSH 858 yang diperoleh dari penangkaran bibit Lampoh Bijeh Kota Langsa.

Untuk kriteria batang bawah yang digunakan dalam penyambungan, bibit harus sehat tidak terserang penyakit, memiliki perakaran yang cukup kuat, sudah memiliki diameter batang yang cukup untuk di lakukan penyambungan, dan berasal dari klon yang unggul.

\section{Batang atas (entres)}

Entres yang digunakan diambil dari pohon induk kakao jenis klon Sulawesi 01 yang diperoleh dari Koperasi Perkebunan Kakao Bireuen Kecamatan Bireuen. Entres dipilih berupa cabang-cabang utama (plagiotrop) yang sehat, tidak sedang bertunas (flush), warna hijau kecoklatan, ukuran entres disesuaikan dengan batang bawah. Semua daun bahan entres dibuang dengan menggunakan gunting pangkas sesuai dengan perlakuan defoliasi. Entres tersebut tetap dipelihara pada pohon induk sampai saat penyambungan. 
Pemotongan entres dilakukan pada pagi hari dan di simpan dengan menggunakan gedebok pisang kemudian dikirim ke Kota Langsa Desa Paya Bujuk Seuleumak Kecamatan Langsa Baro untuk dilakukan penyambungan. Waktu penyambungan dilakukan pada sore hari.

Kriteria entres untuk penyambungan, entres berasal dari klon yang unggul, bebas dari serangan hama dan penyakit, pengambilan entres sebaiknya pada saat pucuk muda, dan minimal tanaman induk sudah berproduksi tiga kali.

\section{Aplikasi Perlakuan}

Lama defoliasi entres dilakukan sesuai dengan perlakuan, yaitu : $\mathrm{D}_{0}=$ tanpa defoliasi, $\mathrm{D}_{1}=$ defoliasi entres 6 hari sebelum penyambungan, $\mathrm{D}_{2}=$ defoliasi entres 12 hari sebelum penyambungan dan $\mathrm{D}_{3}=$ defoliasi entres 18 hari sebelum penyambungan. Entres dipelihara pada tanaman induk sebelum dilakukan penyambungan.

Lama penyimpanan dilakukan sesuai dengan perlakuan, yaitu : $\mathrm{P}_{0}=$ tanpa penyimpanan, $\mathrm{P}_{1}=$ 3 hari penyimpanan, $P_{2}=6$ hari penyimpanan dan $\mathrm{P}_{3}=9$ hari penyimpanan. Penyambungan dilakukan sore hari.

sebagai berikut:

Penyambungan dilakukan

1. Tanaman batang bawah dipotong secara horizontal dan disisakan 3 helaian daun.

2. Bagian ujung batang bawah bekas potongan dibelah sehingga membentuk celah menyerupai "huruf V", sedangkan pada entres dipotong secara miring.

3. Pangkal entres juga disayat pada kedua sisinya hingga meruncing menyerupai huruf "V terbalik", lalu entres disisipkan ke dalam celah dengan posisi tegak lurus (dari atas ke bawah) pada batang bawah.

4. Pada bagian persambungan dilakukan pengikatan dengan menggunakan tali plastik es lilin dengan cara dililit dari arah bawah keatas, kemudian diletakkan kedalam plot dan disungkup dengan plastik es pada bagian entres yang disambung selama 3 minggu atau 21 HSS (Hari Setelah Sambung).

Parameter yang diamati dalam penelitian ini antara lain : persentase bibit jadi (\%); lama tunas melentis (hari); panjang tunas $(\mathrm{cm})$; diameter pangkal tunas $(\mathrm{mm})$ dan jumlah daun (daun).

\section{HASIL DAN PEMBAHASAN}

\section{Pengaruh Defoliasi}

\section{Persentase Bibit Jadi (\%)}

Hasil analisis ragam menunjukkan bahwa defoliasi berpengaruh sangat nyata terhadap persentase bibit jadi (\%). Rata-rata persentase bibit jadi tanaman kakao akibat defoliasi disajikan pada Tabel 2.

Tabel 2. Rata-rata Persentase Bibit Jadi Tanaman Kakao akibat Defoliasi

\begin{tabular}{cc}
\hline Defoliasi & Persentase Bibit Jadi (\%) \\
\hline $\mathrm{D}_{0}$ & $53,13 \mathrm{a}$ \\
$\mathrm{D}_{1}$ & $75,00 \mathrm{~b}$
\end{tabular}




\begin{tabular}{cc}
$\mathrm{D}_{2}$ & $84,38 \mathrm{~b}$ \\
$\mathrm{D}_{3}$ & $75,00 \mathrm{~b}$ \\
\hline BNT 0,05 & 15,18 \\
\hline Keterangan : Angka yang diikuti oleh huruf yang sama berbeda tidak nyata pada uji BNT taraf 5\%.
\end{tabular}

Tabel 2 menunjukkan bahwa persentase bibit jadi akibat perlakuan defoliasi tertinggi diperoleh pada perlakuan $\mathrm{D}_{2} \quad$ (defoliasi entres dilakukan 12 hari sebelum penyambungan) sedangkan terendah terdapat pada perlakuan $\mathrm{D}_{0}$ (tanpa defoliasi). Dari hasil uji BNT taraf 0,05 diketahui bahwa persentase bibit jadi pada perlakuan $\mathrm{D}_{2}$ berbeda nyata dengan $\mathrm{D}_{0}$ (tanpa defoliasi) namun tidak berbeda nyata dengan perlakuan $\mathrm{D}_{1} \quad$ (defoliasi entres dilakukan 6 hari sebelum penyambungan) dan perlakuan $D_{3}$ (defoliasi entres dilakukan 18 hari sebelum penyambungan).

Hal ini menunjukkan bawah defoliasi entres dilakukan 12 hari sebelum penyambungan dapat meningkatkan persentase bibit jadi ini karena kandungan asimilat yang terakumulasi pada entres yang defoliasi pada umur 12 hari Akumulasi asimilat dapat merangsang pembelahan, pembesaran dan deferensiasi sel, yang kemudian mendorong proses pertautan antara batang atas dan bawah, sehingga meningkatkan persentase bibit jadi dibandingkan defolasi yang terlalu cepat (6 hari sebelum penyambungan) dan defoliasi terlalu lama (18 hari sebelum penyambungan).

Menurut Syafrison $d k k$., (2011) masing-masing tanaman memiliki saat defoliasi yang tepat untuk menghasilkan pertumbuhan tunas. Huda (2000) menambahkan hal-hal yang perlu diperhatikan dalam defoliasi adalah waktu defoliasi dalam hal ini tidak boleh dilakukan pada umur tanaman yang terlalu muda karena dapat mengganggu proses pertumbuhan tanaman.

\section{Waktu Muncul Tunas}

Hasil analisis ragam menunjukkan bahwa defoliasi berpengaruh sangat nyata terhadap waktu muncul tunas. Rata-rata waktu muncul tunas akibat defoliasi disajikan pada Tabel 3.

Tabel 3. Rata-rata Waktu Muncul Tunas akibat Defoliasi

\begin{tabular}{cc}
\hline Defoliasi & Waktu muncul tunas (hari) \\
\hline $\mathrm{D}_{0}$ & $19,58 \mathrm{~b}$ \\
$\mathrm{D}_{1}$ & $15,13 \mathrm{a}$ \\
$\mathrm{D}_{2}$ & $14,59 \mathrm{a}$ \\
$\mathrm{D}_{3}$ & $15,81 \mathrm{a}$ \\
\hline BNT $_{0,05}$ & 1,93 \\
\hline
\end{tabular}

Keterangan : Angka yang diikuti oleh huruf yang sama berbeda tidak nyata pada uji BNT taraf 5\%.

Tabel 3 menunjukkan bahwa data rata-rata waktu muncul tunas akibat perlakuan defoliasi yang tercepat pertumbuhannya diperoleh pada perlakuan $\mathrm{D}_{2}$ (defoliasi entres dilakukan 12 hari sebelum penyambungan) sedangkan waktu muncul tunas terlama terdapat pada perlakuan $\mathrm{D}_{0}$ (tanpa defoliasi). Dari hasil uji BNT taraf 0,05 diketahui 
bahwa waktu muncul tunas pada perlakuan $\mathrm{D}_{2}$ berbeda nyata dengan perlakuan $\mathrm{D}_{0}$ tetapi berbeda tidak nyata dengan $\mathrm{D}_{1}$ dan $\mathrm{D}_{3}$.

Hal ini diduga defoliasi pada 12 hari sebelum penyambungan merupakan waktu yang optimal untuk melakukan penyambungan. Ini dikarenakan pada 12 hari sebelum penyambungan akumulasi asimilat akan dapat merangsang pertumbuhan sehingga mempercepat pertumbuhan waktu muncul tunas. Sesuai dengan hasil penelitian Sholikah dan Ashari

Tabel 4. Rata-rata Panjang Tunas pada Umur 30, 45 dan 60 HSS akibat Defoliasi

\begin{tabular}{cccc}
\hline \multirow{2}{*}{ Defoliasi } & \multicolumn{3}{c}{ Panjang Tunas $(\mathrm{cm})$} \\
\cline { 2 - 4 } & $30 \mathrm{HSS}$ & $45 \mathrm{HSS}$ & $60 \mathrm{HSS}$ \\
\hline $\mathrm{D}_{0}$ & $3,46 \mathrm{a}$ & $5,04 \mathrm{a}$ & $5,99 \mathrm{a}$ \\
$\mathrm{D}_{1}$ & $4,43 \mathrm{bc}$ & $6,96 \mathrm{~b}$ & $8,09 \mathrm{~b}$ \\
$\mathrm{D}_{2}$ & $4,68 \mathrm{c}$ & $7,08 \mathrm{~b}$ & $8,35 \mathrm{~b}$ \\
$\mathrm{D}_{3}$ & $4,25 \mathrm{~b}$ & $6,84 \mathrm{~b}$ & $7,95 \mathrm{~b}$ \\
\hline $\mathrm{BNT}_{0,05}$ & 0,32 & 0,80 & 0,78 \\
\hline
\end{tabular}

Keterangan : Angka yang diikuti oleh huruf yang sama pada kolom yang sama berbeda tidak nyata pada uji BNT taraf 5\%.

Tabel 4 menunjukkan bahwa data rata-rata panjang tunas akibat perlakuan defoliasi yang tertinggi pertumbuhannya diperoleh pada perlakuan $\mathrm{D}_{2}$ (defoliasi entres dilakukan 12 hari sebelum penyambungan) sedangkan panjang tunas terendah terdapat pada perlakuan $\mathrm{D}_{0}$ (tanpa defoliasi). Dari hasil uji BNT taraf 0,05 diketahui bahwa panjang tunas umur 30 HSS pada perlakuan $D_{2}$ berbeda nyata dengan perlakuan $D_{3}$ dan $D_{0}$ tetapi berbeda tidak nyata dengan $D_{1}$. Sedangkan pada umur 45 dan 60 HSS perlakuan $D_{2}$ berbeda nyata dengan perlakuan $\mathrm{D}_{0}$ namun berbeda tidak nyata dengan $\mathrm{D}_{1}$ dan perlakuan $\mathrm{D}_{3}$.

Hal ini diduga defoliasi entres pada 12 hari sebelum penyambungan jaringan kalus telah terbentuk sempurna sehingga batang bawah
(2017) defoliasi batang atas 12 hari setelah penyambungan cenderung meningkatkan pertumbuhan tanaman durian hasil grafting.

\section{Panjang Tunas}

Hasil analisis ragam menunjukkan bahwa defoliasi berpengaruh sangat nyata terhadap panjang tunas umur 30, 45 dan 60 HSS. Rata-rata panjang tunas pada umur 30, 45 dan 60 HSS akibat defoliasi disajikan pada Tabel 4. 
Hasil analisis ragam

HSS. Rata-rata Diameter tunas pada menunjukkan bahwa defoliasi umur 30, 45 dan 60 HSS akibat berpengaruh tidak nyata terhadap diameter tunas umur 30, 45 dan 60 defoliasi disajikan pada Tabel 5.

Tabel 5. Rata-rata Diameter tunas pada Umur 30, 45 dan 60 HSS akibat Defoliasi

\begin{tabular}{cccc}
\hline \multirow{2}{*}{ Defoliasi } & \multicolumn{3}{c}{ Diameter tunas $(\mathrm{cm})$} \\
\cline { 2 - 4 } & $30 \mathrm{HSS}$ & $45 \mathrm{HSS}$ & $60 \mathrm{HSS}$ \\
\hline $\mathrm{D}_{0}$ & 2,38 & 3,04 & 3,73 \\
$\mathrm{D}_{1}$ & 2,79 & 3,47 & 4,33 \\
$\mathrm{D}_{2}$ & 2,78 & 3,58 & 4,39 \\
$\mathrm{D}_{3}$ & 2,66 & 3,41 & 4,22 \\
\hline
\end{tabular}

Diduga pertumbuhan diameter tunas tidak berpengaruh terhadap defoliasi. Hal ini dikarenakan pertumbuhan diameter tunas dipengaruhi oleh faktor genetik sehingga tidak menunjukkan pengaruh antar perlakuan yang diuji. Sesuai dengan pendapat Fosket, (1994) faktor yang mempengaruhi pertumbuhan suatu bahan tanam, termasuk faktor eksternal (lingkungan seperti iklim, tanah dan terapan teknologi) dan faktor internal (genetik termasuk kualitas dan ukuran massa sel meristem yang terdapat pada suatu bahan tanam).

\section{Jumlah Daun}

Hasil analisis ragam menunjukkan bahwa defoliasi berpengaruh sangat nyata terhadap jumlah daun umur 30,45 dan 60 HSS. Rata-rata Jumlah daun pada umur 30, 45 dan 60 HSS akibat defoliasi disajikan pada Tabel 6.

Tabel 6. Rata-rata Jumlah daun pada Umur 30, 45 dan 60 HSS akibat Defoliasi

\begin{tabular}{cccc}
\hline \multirow{2}{*}{ Defoliasi } & \multicolumn{3}{c}{ Jumlah daun (helai) } \\
\cline { 2 - 4 } & $30 \mathrm{HSS}$ & $45 \mathrm{HSS}$ & $60 \mathrm{HSS}$ \\
\hline $\mathrm{D}_{0}$ & $2,47 \mathrm{a}$ & $6,47 \mathrm{a}$ & $9,75 \mathrm{a}$ \\
$\mathrm{D}_{1}$ & $3,44 \mathrm{~b}$ & $9,25 \mathrm{c}$ & $13,13 \mathrm{bc}$ \\
$\mathrm{D}_{2}$ & $4,19 \mathrm{c}$ & $10,22 \mathrm{~d}$ & $13,91 \mathrm{c}$ \\
$\mathrm{D}_{3}$ & $2,94 \mathrm{ab}$ & $8,22 \mathrm{~b}$ & $12,13 \mathrm{~b}$ \\
\hline BNT $_{0,05}$ & 0,52 & 0,71 & 1,01 \\
\hline
\end{tabular}

Keterangan : Angka yang diikuti oleh huruf yang sama pada kolom yang sama berbeda tidak nyata pada uji BNT taraf $5 \%$.

Tabel 6 menunjukkan bahwa data rata-rata jumlah daun akibat perlakuan defoliasi yang terbanyak pertumbuhannya diperoleh pada perlakuan $\mathrm{D}_{2} \quad$ (defoliasi entres dilakukan 12 hari sebelum penyambungan) sedangkan jumlah daun terendah terdapat pada perlakuan $\mathrm{D}_{0}$ (tanpa defoliasi). Dari hasil uji BNT taraf 0,05 diketahui bahwa jumlah daun umur 30 dan 45 HSS tertinggi diperoleh pada 
perlakuan $\mathrm{D}_{2}$ yang berbeda nyata dengan $\mathrm{D}_{1}, \mathrm{D}_{3}$ dan perlakuan $\mathrm{D}_{0}$. Sedangkan pada umur 60 HSS perlakuan $D_{2}$ berbeda nyata dengan perlakuan $\mathrm{D}_{3}$ dan $\mathrm{D}_{0}$ tetapi berbeda tidak nyata dengan $D_{1}$. Hal ini diduga defoliasi entres pada 12 hari sebelum penyambungan merupakan waktu yang tepat sehingga pertautan sambungan telah sempurna sehingga tidak terjadi gangguan translokasi asimilat.

Penyambungan yang terlalu awal seperti tanpa defoliasi dan 6 hari sebelum penyambungan dapat mengakibatkan pertumbuhan batang atas terlalu cepat. Pertumbuhan batang atas yang terlalu cepat akan memerlukan asimilat yang banyak sementara pertautan sambungan belum sempurna sehingga terjadi gangguan translokasi asimilat. Akibatnya pertumbuhan tunas dan daun sambungan menjadi terganggu. Sebaliknya defoliasi entres yang terlambat pada 18 hari sebelum penyambungan akan mengakibatkan batang atas tumbuh lebih lambat. Defoliasi entres pada saat yang optimal berkaitan erat dengan keserasian laju tumbuh batang atas dengan batang bawah sehingga tercipta kompatibilitas pertumbuhan.

Menurut Syafrison $d k k$., (2011) masing-masing tanaman memiliki saat defoliasi yang tepat untuk menghasilkan tunas terpanjang pada hasil sambungan, defoliasi yang dilakukan terlalu awal dapat menyebabkan pertumbuhan batang yang terlalu cepat akan memerlukan asimilat yang banyak sementara pertautan sambungan belum sempurna sehingga terjadi gangguan translokasi asimilat, akibatnya pertumbuhan tunas dan daun sambungan menjadi terganggu. Sebaliknya defoliasi entres yang terlambat akan mengakibatkan batang atas tumbuh lebih lambat.

\section{Pengaruh Lama Penyimpanan Entres Persentase Bibit Jadi (\%)}

Hasil analisis ragam menunjukkan bahwa lama penyimpanan entres berpengaruh sangat nyata terhadap persentase bibit jadi (\%). Rata-rata persentase bibit jadi tanaman kakao akibat lama penyimpanan entres disajikan pada Tabel 7.

Tabel 7. Rata-rata Persentase Bibit Jadi Tanaman Kakao akibat Lama penyimpanan entres

\begin{tabular}{cc} 
Lama Penyimpanan Entres & Persentase Bibit Jadi (\%) \\
\hline $\mathrm{P}_{0}$ & $90,63 \mathrm{~b}$ \\
$\mathrm{P}_{1}$ & $71,88 \mathrm{a}$ \\
$\mathrm{P}_{2}$ & $65,63 \mathrm{a}$ \\
$\mathrm{P}_{3}$ & $59,38 \mathrm{a}$ \\
\hline BNT 0,05 & 15,18
\end{tabular}

Keterangan : Angka yang diikuti oleh huruf yang sama berbeda tidak nyata pada uji BNT taraf 5\%.

Tabel 7 menunjukkan bahwa persentase bibit jadi akibat perlakuan lama penyimpanan entres tertinggi diperoleh pada perlakuan $\mathrm{P}_{0}$ (tanpa penyimpanan) sedangkan terendah terdapat pada perlakuan $\mathrm{P}_{3}(9$ hari penyimpanan). Dari hasil uji BNT taraf 0,05 diketahui bahwa persentase bibit jadi pada perlakuan $\mathrm{P}_{0}$ (tanpa penyimpanan) berbeda nyata dengan semua perlakuan. Hal ini diduga pertumbuhan entres lebih 
baik tanpa dilakukan penyimpan karena apabila dilakukan penyimpanan dapat menurunkan kadar air pada entres dibandingkan dengan entres yang langsung dilakukan penyambungan.

Sesuai dengan penelitian yang dilakukan oleh Saefudin dan Wardiana (2015) yang menyatakan bahwa persentasi keberhasilan okulasi tanaman karet dipengaruhi oleh periode penyimpanan entres. Penyimpanan entres selama dua dan empat hari menghasilkan persentase keberhasilan okulasi yang nyata lebih rendah dibandingkan entres yang tidak diperlakukan penyimpanan. Saefudin dan Wardiana (2015) menambahkan semakin singkat waktu entres mengalami penyimpanan (penundaan) maka makin tinggi persentase keberhasilan grafting.

\section{Waktu Muncul Tunas}

$\begin{array}{crr}\text { Hasil } & \text { analisis } & \text { ragam } \\ \text { menunjukkan } & \text { bahwa } & \text { lama }\end{array}$ penyimpanan entres berpengaruh sangat nyata terhadap waktu muncul tunas. Rata-rata waktu muncul tunas akibat lama penyimpanan entres disajikan pada Tabel 8.

Tabel 8. Rata-rata Waktu Muncul Tunas akibat Lama penyimpanan entres

\begin{tabular}{cc}
\hline Lama Penyimpanan Entres & Waktu muncul tunas (hari) \\
\hline $\mathrm{P}_{0}$ & $13,31 \mathrm{a}$ \\
$\mathrm{P}_{1}$ & $16,75 \mathrm{~b}$ \\
$\mathrm{P}_{2}$ & $17,10 \mathrm{~b}$ \\
$\mathrm{P}_{3}$ & $17,95 \mathrm{~b}$ \\
\hline BNT $_{0,05}$ & 1,13 \\
\hline
\end{tabular}

Keterangan : Angka yang diikuti oleh huruf yang sama berbeda tidak nyata pada uji BNT taraf 5\%.

Tabel 8 menunjukkan bahwa data rata-rata waktu muncul tunas akibat perlakuan lama penyimpanan entres tercepat diperoleh pada perlakuan $\mathrm{P}_{0}$ (tanpa penyimpanan) sedangkan waktu muncul tunas terlama terdapat pada perlakuan $\mathrm{P}_{3}(9$ hari penyimpanan). Dari hasil uji BNT taraf 0,05 diketahui bahwa waktu muncul tunas pada perlakuan $\mathrm{P}_{0}$ (tanpa penyimpanan) berbeda nyata dengan semua perlakuan. Hal ini menunjukkan bawah penyambungan entres lebih baik dilakukan tanpa penyimpanan karena dalam penyimpanan terjadi penguapan air dari jaringan bibit sehingga semakin lama bibit disimpan maka bibit akan layu dan kering. Selain itu penurunan bobot bibit juga berpengaruh pada waktu muncul tunas. Menurut Rahardjo (2007) daya tumbuh akibat penyimpanan dipengaruhi adanya penyusutan kadar air. Yohanes, (2011) menambahkan penyimpanan entres yang lebih lama dapat mengakibatkan habisnya cadangan makanan dan kadar air pada entres untuk proses metabolisme selama penyimpanan.

\section{Panjang Tunas}

Hasil analisis ragam menunjukkan bahwa lama penyimpanan entres berpengaruh sangat nyata terhadap panjang tunas umur 30, 45 dan 60 HSS. Rata-rata panjang tunas pada umur 30, 45 dan 60 HSS akibat lama penyimpanan entres disajikan pada Tabel 9. 
Tabel 9. Rata-rata Panjang Tunas pada Umur 30, 45 dan 60 HSS akibat Lama penyimpanan entres

\begin{tabular}{cccc}
\hline \multirow{2}{*}{ Lama Penyimpanan Entres } & \multicolumn{3}{c}{ Panjang Tunas $(\mathrm{cm})$} \\
\cline { 2 - 4 } & $30 \mathrm{HSS}$ & $45 \mathrm{HSS}$ & $60 \mathrm{HSS}$ \\
\hline $\mathrm{P}_{0}$ & $4,93 \mathrm{c}$ & $7,80 \mathrm{c}$ & $8,82 \mathrm{c}$ \\
$\mathrm{P}_{1}$ & $4,29 \mathrm{~b}$ & $6,56 \mathrm{~b}$ & $7,75 \mathrm{~b}$ \\
$\mathrm{P}_{2}$ & $4,06 \mathrm{~b}$ & $5,98 \mathrm{ab}$ & $7,14 \mathrm{ab}$ \\
$\mathrm{P}_{3}$ & $3,53 \mathrm{a}$ & $5,59 \mathrm{a}$ & $6,67 \mathrm{a}$ \\
\hline $\mathrm{BNT}_{0,05}$ & 0,32 & 0,59 & 0,76 \\
\hline
\end{tabular}

Keterangan : Angka yang diikuti oleh huruf yang sama pada kolom yang sama berbeda tidak nyata pada uji BNT taraf 5\%.

Tabel 9 menunjukkan bahwa panjang tunas umur 30,45 dan 60 HSS akibat perlakuan lama penyimpanan entres tertinggi diperoleh pada perlakuan $\mathrm{P}_{0}$ (tanpa penyimpanan) sedangkan terendah terdapat pada perlakuan $\mathrm{P}_{3}(9$ hari penyimpanan). Dari hasil uji BNT taraf 0,05 diketahui bahwa panjang tunas pada perlakuan $\mathrm{P}_{0}$ (tanpa penyimpanan) berbeda nyata dengan semua perlakuan. Hal ini dikarenakan semakin cepat entres disambung atau tanpa dilakukan penyimpanan maka semakin besar persentase sambung hidup entres. Diduga entres yang cepat disambungkan masih memiliki banyak cadangan makanan, semakin lama entres disimpan maka kandungan cadangan makanan akan semakin rendah.

Menurut Mahfudin, (2000) entres harus segera digunakan untuk okulasi atau sambung pucuk karena penundaan okulasi dan penyambungan lebih satu hari sejak pengambilan entres akan memperlambat pertumbuhan. Yohanes, (2011) menyatakan selama penyimpanan, entres tetap melakukan proses respirasi, semakin lama proses respirasi berlangsung maka banyak cadangan makanan yang digunakan sehingga dapat mempengaruhi pertumbuhan entres.

\section{Diameter Tunas}

Hasil analisis ragam menunjukkan bahwa lama penyimpanan entres berpengaruh tidak nyata terhadap diameter tunas umur 30, 45 dan 60 HSS. Rata-rata Diameter tunas pada umur 30, 45 dan 60 HSS akibat lama penyimpanan entres disajikan pada Tabel 10.

Tabel 10. Rata-rata Diameter tunas pada Umur 30, 45 dan 60 HSS akibat Lama penyimpanan entres

\begin{tabular}{cccc}
\hline \multirow{2}{*}{ Lama Penyimpanan Entres } & \multicolumn{3}{c}{ Diameter tunas $(\mathrm{cm})$} \\
\cline { 2 - 4 } & $30 \mathrm{HSS}$ & $45 \mathrm{HSS}$ & $60 \mathrm{HSS}$ \\
\hline $\mathrm{P}_{0}$ & 2,78 & 3,43 & 4,31
\end{tabular}




$\begin{array}{llll}\mathrm{P}_{1} & 2,74 & 3,48 & 4,28 \\ \mathrm{P}_{2} & 2,67 & 3,45 & 4,23 \\ \mathrm{P}_{3} & 2,42 & 3,14 & 3,84\end{array}$

\section{Diduga pertumbuhan}

diameter tunas tidak berpengaruh terhadap lama penyimpanan. Hal ini disebabkan kandungan cadangan makanan dalam keadaan seimbang sehingga pembelahan pembesaran dan diferensiasi sel juga berjalan dengan seimbang. Dalam kondisi seimbang ini, kandungan cadangan makanan yang terdapat pada masingmasing perlakuan panjang entres sama-sama memadai untuk terjadinya

penyambungan

(Parsaulian $d k k .$, 2012).

\section{Jumlah daun}

$\begin{array}{cr}\text { Hasil analisis } & \text { ragam } \\ \text { menunjukkan } & \text { bahwa }\end{array}$ penyimpanan entres berpengaruh sangat nyata terhadap jumlah daun umur 30, 45 dan 60 HSS. Rata-rata Jumlah daun pada umur 30, 45 dan 60 HSS akibat lama penyimpanan entres disajikan pada Tabel 11.

Tabel 11. Rata-rata Jumlah daun pada Umur 30, 45 dan 60 HSS akibat Lama penyimpanan entres

\begin{tabular}{cccc}
\hline \multirow{2}{*}{ Lama Penyimpanan Entres } & \multicolumn{3}{c}{ Jumlah daun (helai) } \\
\cline { 2 - 4 } & $30 \mathrm{HSS}$ & $45 \mathrm{HSS}$ & $60 \mathrm{HSS}$ \\
\hline $\mathrm{P}_{0}$ & $4,16 \mathrm{c}$ & $9,84 \mathrm{~d}$ & $14,38 \mathrm{c}$ \\
$\mathrm{P}_{1}$ & $3,44 \mathrm{~b}$ & $8,88 \mathrm{c}$ & $12,22 \mathrm{~b}$ \\
$\mathrm{P}_{2}$ & $2,97 \mathrm{ab}$ & $8,16 \mathrm{~b}$ & $11,72 \mathrm{~b}$ \\
$\mathrm{P}_{3}$ & $2,47 \mathrm{a}$ & $7,28 \mathrm{a}$ & $10,59 \mathrm{a}$ \\
\hline $\mathrm{BNT}_{0,05}$ & 0,52 & 0,71 & 1,01 \\
\hline
\end{tabular}

Keterangan : Angka yang diikuti oleh huruf yang sama pada kolom yang sama berbeda tidak nyata pada uji BNT taraf 5\%.

Tabel 11 menunjukkan bahwa panjang tunas umur 30, 45 dan 60 HSS akibat perlakuan lama penyimpanan entres terbanyak diperoleh pada perlakuan $\mathrm{P}_{0}$ (tanpa penyimpanan) sedangkan terendah terdapat pada perlakuan $\mathrm{P}_{3}$ ( 9 hari penyimpanan). Dari hasil uji BNT taraf 0,05 diketahui bahwa panjang tunas pada perlakuan $\mathrm{P}_{0}$ (tanpa penyimpanan) berbeda nyata dengan semua perlakuan.

Hal ini dikarenakan bahwa daya tumbuh entres sangat dipengaruhi oleh lamanya waktu penyimpanan, semakin cepat dilakukan penyambungan atau tanpa penyimpanan maka semakin baik hal ini dikarenakan kesegaran entres masih terjaga sehingga dapat kmeningkatkan jumlah daun karena semakin lama disimpan maka semakin menurun daya tumbuh pada entres. Penyimpanan yang lama sejak pemotongan dapat menurunkan kadar air dan nutrisi yang terkandung dalam entres sehingga dapat menurunkan daya tumbuh ketika dilakukan penyambungan. Kesegaran entres perlu dijaga untuk menjamin tingkat keberhasilan pada penyambungan (Rahardjo, 2007).

\section{Pengaruh Interaksi Antara Defoliasi dan Lama Penyimpanan Entres}

Tidak terjadinya interaksi antara kedua perlakuan diduga kedua 
faktor penguji yaitu perlakuan defoliasi dan lama penyimpanan entres memiliki waktu dan rekasi serta cara kerja yang berbeda dalam mempengaruhi pertumbuhan bibit kakao Hal ini diindikasikan oleh tidak terjadinya peningkatan interaksi diantara kedua perlakuan.

\section{KESIMPULAN DAN SARAN}

\section{Kesimpulan}

1. Defoliasi berpengaruh sangat nyata terhadap persentase bibit jadi, waktu muncul mata tunas, panjang tunas dan jumlah daun. Tetapi tidak berpengaruh nyata terhadap parameter diameter batang tunas. Hasil pengamatan terbaik diperoleh pada perlakuan $\mathrm{D}_{2}$ (defoliasi entres dilakukan 12 hari sebelum penyambungan).

2. Lama penyimpanan entres berpengaruh sangat nyata terhadap persentase bibit jadi, waktu muncul mata tunas, panjang tunas dan jumlah daun. Tetapi tidak berpengaruh nyata terhadap parameter diameter batang tunas. Hasil pengamatan terbaik diperoleh pada perlakuan $\mathrm{P}_{0}$ (tanpa penyimpanan).

3. Interaksi antara defoliasi dan lama penyimpanan entres berpengaruh tidak nyata terhadap semua perlakuan.

\section{Saran}

Untuk dapat meningkatkan keberhasilan sambung pucuk bibit kakao dianjurkan untuk melakukan defoliasi entres 12 hari sebelum penyambungan atau melakukan penyambungan tanpa dilakukan penyimpanan entres.
Perlakuan defoliasi dan lama penyimpanan entres memiliki cara kerja masing-masing. Sesuai dengan hasil penelitian Kurniastuti, (2014) bahwa tidak ada pengaruh interaksi antara defoliasi dan lama penundaan sambung pada keberhasilan sambung bibit sirsak.

\section{DAFTAR PUSTAKA}

Badan Pusat Statistik (BPS). 2014. Tabel Ekspor Menurut Komoditi Tahun 2013.<http://www.bps.go.id/e ximframe.php?kat=2\&id_sub $y e k=08 \&$ notab $=50>$. Diakses tanggal 05 Mei 2018.

Fosket, D, E. 1994 Plant Growth and Development a Molecular Appoach. Academic Press. New York, London, Sydney. p.298-331.

Huda, K. 2000. Pengaruh Umur Defolasi dan Dosis Pemupukan Urea terhadap Laju Asimilasi Bersih Rumput Gajah (Pennisetum purpureum).

Jurnal Agronomi. 2 (2) : 1-23.

Hanafiah, K.A. 2014. Rancangan Percobaan Teori dan Aplikasi. Raja Grafindo Persada. Jakarta.

Lukman, W. 2004. Teknik Sambung Pucuk Menggunakan Stadium Entres Yang Didefoliasi pada Jambu Mete Wawan Lukman 1. Buletin Teknik Pertanian, 9 (3), 13-15.

Kurniastuti, T. 2014. Pengaruh Defoliasi Daun Entres dan Lama Tunda Sambung pada Keberhasilan Penyambungan Bibit Sirsak (Annona muricata L.). Jurnal 
Grafting. 4 (1): 01 - 11 ISSN : 2088-2440.

Mahfudin. 2000. Pengaruh Lama Penyimpanan Entres terhadap Pertumbuhan Benih Hasil Okulasi. Fakultas Pertanian Universitas Juanda, Bogor. Hlm. 21.

Parsaulian, T., Putu, D., Patriani, B. 2012. Pengaruh Panjang Entres terhadap Keberhasilan Sambung Pucuk Tanaman Jambu Air. Jurnal Sains Mahasiswa Pertanian. 1 (1) : 1-9.

Rahardjo, P., 2007. Pengaruh lama penyimpanan entres terhadap penyambungan bibit kakao. Warta Pusat Penelitian Kopi dan Kakao 23 (3) : 142-148.

Rosmaiti., Saputra, I. 2019. Kombinasi Waktu Defoliasi Entres dan Model Sambung Pucuk terhadap Pertumbuhan Bibit Kakao (Theobroma cacao, L). Jurnal Ilmiah Pertanian, 14 (2) : 1-24.

Sholikah, A., Ashari, S. 2017. Pengaruh Saat Defoliasi Batang Atas terhadap Pertumbuhan dan Keberhasilan Grafting Durian ( Durio zibethinus Murr.). Jurnal Produksi Tanaman. 5 (3) : 441-450.

Sudarto. 2000. Respon beberapa Varietas Entres Mangga (Mangifera indica L.) pada Perbedaan Waktu Defolasi terhadap Pertumbuhan Bibit Secara Grafting. Jurnal Agronomi. 2 (3) : 1-9.
Syafrison, A., Syarif., Akhir, N. 2011. Pengaruh Saat Defoliasi Entres terhadap Pertumbuhan Sambung Pucuk Kakao (Theobroma cacao L. ) dengan Batang Bawah yang Mempunyai Jumlah Daun Berbeda. Laporan Penelitian Balai Penelitian Perkebunan Propinsi Sumatera Barat. Padang.

Saefudin., Ferri, Y. 2009. Pengaruh Panjang Entres terhadap Keberhasilan Sambung Pucuk dan Pertumbuhan Benih Jambu Mete. Buletin RISTRI. 2 (2) : 121-124.

Saefudin., Wardiana. E. 2015. Pengaruh Periode dan Media Penyimpanan Entres Terhadap Keberhasilan Okulasi Hijau dan Kandungan Air Entres pada Tanaman Karet. Jurnal TIDP. 2 (1) : $13-20$.

Wahyudi, T., Pujianto., Pangabean, T.R. 2009. Panduan Lengkap Kakao Manajemen Agribisnis dari Hulur Hingga Hilir. Penebar Swadaya. Jakarta.

Yohanes, S. M. 2011. Pengaruh Jenis Klon dan Lama Penyimpanan Entres terhadap Pertumbuhan Sambung Samping Kakao (Theobroma cacao L.). Tesis. Program Pascasarjana Universitas Udayana. Denpasar. 